\title{
Abundance of Viscum in Central Poland: Results from a Large-Scale Mistletoe Inventory ${ }^{\dagger}$
}

\author{
Roman Wójcik and Wojciech Kędziora *
}

Citation: Wójcik, R.; Kędziora, W. Abundance of Viscum in Central Poland-Results from a Large-Scale Mistletoe Inventory. Environ. Sci. Proc. 2021, 3, 98. https://doi.org/ 10.3390/IECF2020-07883

Academic Editors: Angela Lo Monaco, Cate Macinnis-Ng and Om P. Rajora

Published: 11 November 2020

Publisher's Note: MDPI stays neutral with regard to jurisdictional claims in published maps and institutional affiliations.

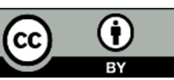

Copyright: (C) 2020 by the authors. Licensee MDPI, Basel, Switzerland. This article is an open access article distributed under the terms and conditions of the Creative Commons Attribution (CC BY) license (http://creativecommons.org/licenses/by/4.0/).
Department of Forest Management, Dendrometry and Forest Economics, Institute of Forest Sciences, Warsaw University of Life Sciences-SGGW, 02-787 Warszawa, Poland; roman.wojcik@wl.sggw.pl

* Correspondence: wojciech.kedziora@wl.sggw.pl; Tel.: +48-22-59-38-204

† Presented at the 1st International Electronic Conference on Forests - Forests for a Better Future: Sustainability, Innovation, Interdisciplinarity, 15-30 November 2020; Available online: https://iecf2020.sciforum.net.

\begin{abstract}
Mistletoe (Viscum album L.) is a semi-parasitic plant, and in moderate abundance, it does not pose a lethal threat to a tree. However, recent droughts have made a heavy impact on forests, and in recent years, mistletoe began to appear on a larger scale in regions and in places where it has never been a threat before. The main purpose of this research is to carry out a large-scale mistletoe inventory in central Poland for assessing the number of mistletoe on individual trees and in the stands, as well as to test a new inventory method adapted to Polish conditions. It is based on random sample plots, each consisting of 15 trees on which the impact of mistletoe is assessed. On every sample plot, the mistletoe occurrence, location in the crown, estimate of the percentage within the crown, and the number of mistletoe on a tree are assessed. In addition, for further analysis, information about stands (forest habitat type, site index) as well as measured trees (age, diameter, Kraft class, crown length, loss of assimilation apparatus, crown type) levels is recorded. Research undertaken in Kozienice Forest (100 km south from Warsaw) took into account 100 sample plots on which 1500 trees were assessed. Preliminary results show that $16 \%$ of trees are infected by mistletoe, more than $25 \%$ of which are infected heavily by more than 6 specimens.
\end{abstract}

Keywords: Viscum; assessment methods; mistletoe rating system

\section{Introduction}

Scots pine (Pinus sylvestris L.) is the most common tree species in Polish forests. Its share is currently estimated at approximately $58.2 \%$ in 9 million ha of forests. The amount of pine is significantly reduced in favor of deciduous species as a result of the reconstruction of stands. However, due to habitat conditions, its share will be greater than that of other forest-forming species.

The mistletoe (Viscum) found on deciduous species until recently has begun to spread, also on coniferous species. The mistletoe found on the pine tree (Viscum album ssp. austriacum (Wiesb.) Vollm.) has become a big problem in forest management. For example, in Germany, near Brandenburg, the infestation rate is increasing. It was 1\% in 2009, and in 2015 as much as 11\% [1]. The dynamics of the growth of mistletoe in cooler areas is related to the recently observed climate changes [2].

Pine and mistletoe are evergreen species, which makes them compete in the spring. Pine begins to vegetate later than mistletoe, which begins its activity in late winter. The current temperature changes, related to changing climate conditions [3], are favorable for mistletoe.

Trees that become infected with mistletoe fruit and bloom less. They become an easier target for pest attacks. Sometimes, the paralysis leads to the death of the host [4]. The place of the mistletoe infection can facilitate the penetration of pathogenic organisms, 
mainly fungi. Consequently, this causes further unfavorable factors to which the tree is exposed [5].

Currently, there are no data on the spread of mistletoe in Poland. The presence of a species in large numbers creates opportunities for increased pest risk. Mistletoe as a thermophilic species has an easier way of growing on a larger scale and at a faster pace. Severe mistletoe infections on pine, the most common forest-forming species in Poland, can potentially contribute to a large economic loss [6].

To create an effective method of fighting mistletoe, it is necessary to determine the scale and scope of the problem. This article presents the results of a large-scale mistletoe inventory: the number of trees infected, the degree of this infestation in order to determine the need for further assessment, and the ways to improve the methods of assessing the presence of mistletoe.

The aim of the study was to assess the presence of mistletoe on the Scots pine in the Kozienice Forest District in central Poland (Figure 1) and to analyze the results, depending on the selected features of trees and stands.
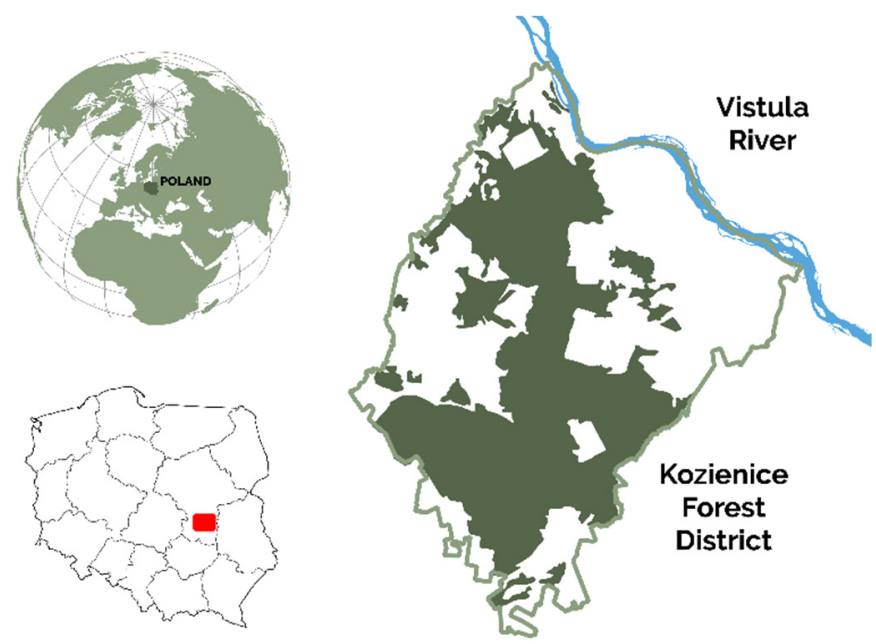

Figure 1. Kozienice Forest District forests along with their localization.

\section{Materials and Methods}

Sample plots were established in 2019 in the Kozienice Forest District, one of three forest districts of the Kozienice Primeval Forest. On the basis of preliminary measurements, it was assumed that for the mistletoe inventory, the coefficient of variation in the mistletoe occurrence is $40 \%$. One hundred permanent study plots were established randomly using a square grid, each with a constant number of 15 trees in stands older than 20 years. Only pine-dominated stands in their typical habitats were examined. Fifteen hundred trees were inventoried regarding mistletoe infestation. The following features were assessed on individual trees: Kraft class, type of crown, crown length, dbh, percentage of defoliation, percentage of mistletoe, location of mistletoe on the tree, and number of mistletoe specimens. Only trees of Kraft classes I, II, and III (dominant, dominant, and co-dominant) were taken into account in the study. The following types of crowns were determined: typical, spreader, one sided, and umbrella shaped. Estimation of the proportion of the crown (crown length) was assessed in gradients of $5 \%$. The measurement was made relative to the total height of the tree. For each tree, the loss of the assimilation apparatus was estimated using a standard procedure [7]. Estimating the percentage of mistletoe in relation to the volume of the crown was rounded to the full $5 \%$. The location of mistletoe within the crown was assessed, divided into the top, middle, and bottom of the crown. The number of mistletoe copies from 1 to 5 was also recorded. If the number was greater than 5, it was difficult to separate the mistletoe specimens and they were recorded 
as 6 and more (6+). Along with the mistletoe inventory, we obtained information regarding the stands: forest habitat type, stand age, site index, and stand crown density.

\section{Results}

Results from the mistletoe inventory showed that of 1500 measured trees, 238 (16\%) were infected by the parasite. The number of mistletoe specimens on trees varied: $33 \%$ were infected by only one, $27 \%$ by six or more, and the remaining $40 \%$ had two to five. The infection pattern differed with different stand characteristics. Trees of a higher biosocial status tended to be more infected (Figure 2).

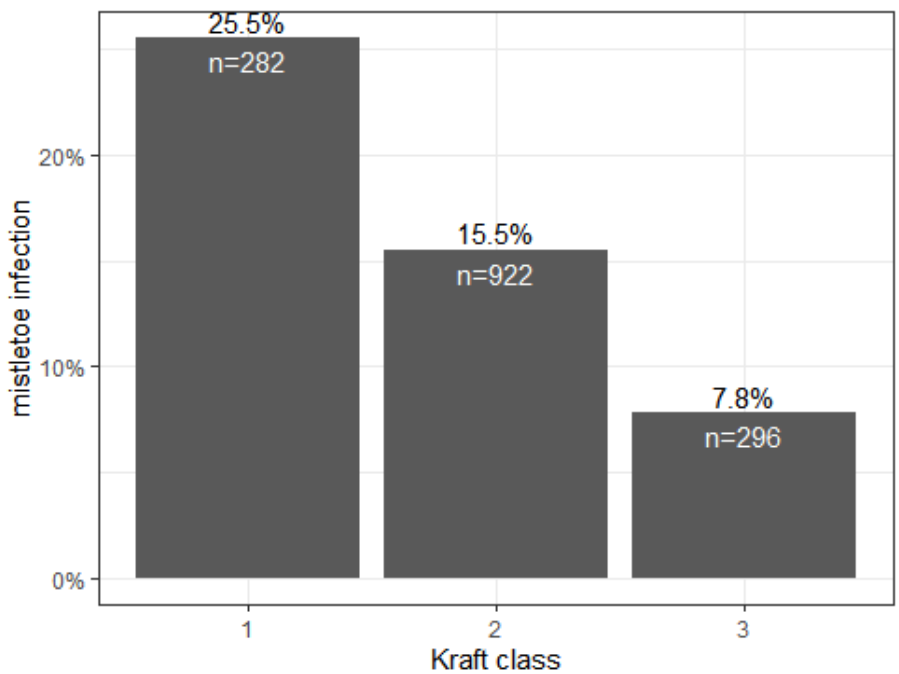

Figure 2. Impact of biosocial classes on mistletoe infection in the Kozienice Forest District. The percentage shows how many trees in that class were infected, whereas $n$ shows the total number investigated in each group.

Results suggested that the closer the crowns in the stand grow, the less the mistletoe infection they get (Figure 3). Mistletoe tends to prefer more sunlight, infecting more than $20 \%$ of trees growing under low-crown-density conditions and less than $5 \%$ under fullcrown-density conditions.

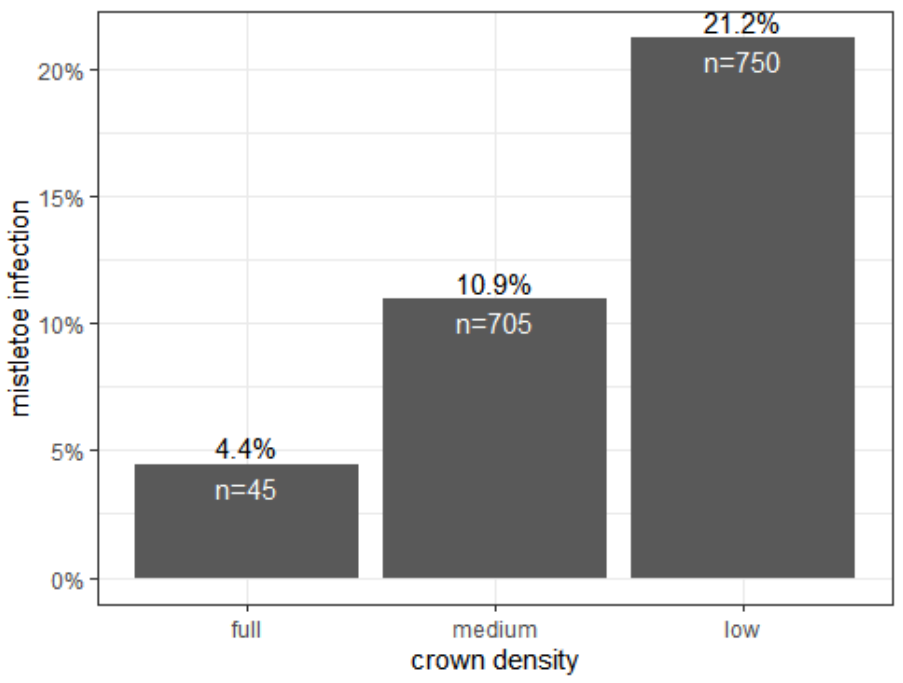

Figure 3. Impact of crown densities on mistletoe infection in the Kozienice Forest District. 
The site index, showing the potential for tree growth, is also connected to mistletoe infection. Trees growing under better habitat conditions and being more vigorous showed less mistletoe infection (Figure 4). A Scots pine that reaches a height of $32 \mathrm{~m}$ at the age of 100 years is three times less likely to be infected than one that is going to reach a height of $24 \mathrm{~m}$.

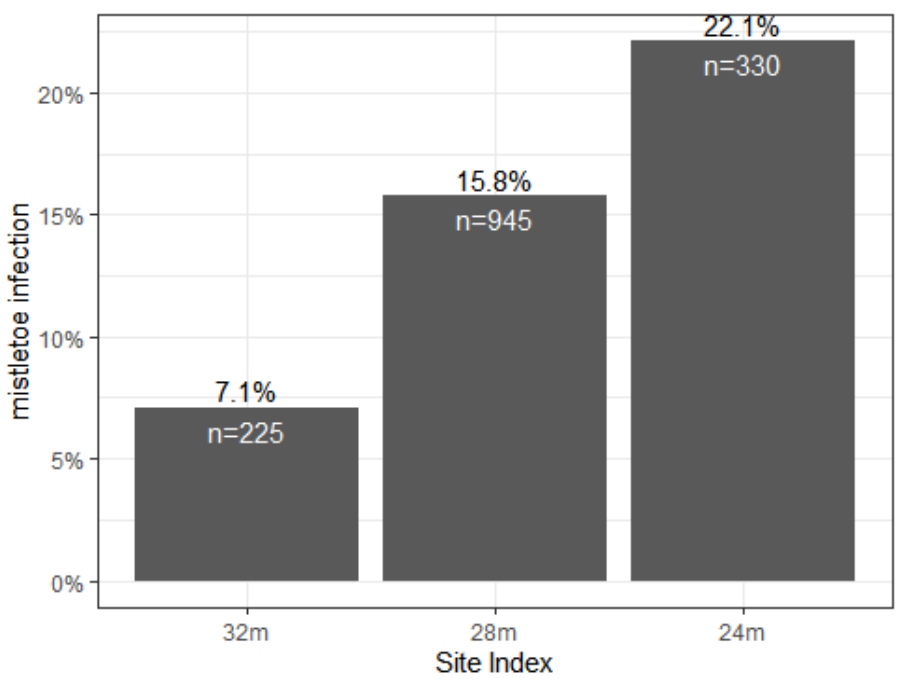

Figure 4. Impact of the site index on mistletoe infection in the Kozienice Forest District.

The biggest differences in mistletoe infection were observed among age classes (Figure 5). The infection severity ranged from $0 \%$ for the youngest stands, showing continual growth along the way up to $67 \%$ for the oldest ones.

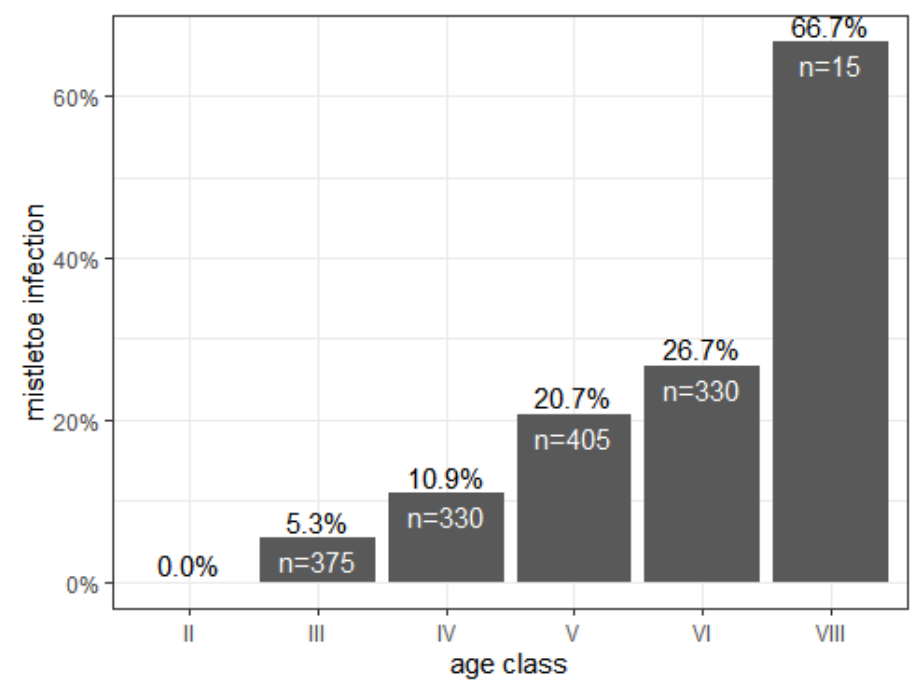

Figure 5. Impact of the age class on mistletoe infection in the Kozienice Forest District.

We did not see any connection between mistletoe infection and forest habitat conditions.

\section{Conclusions}

1. The share of trees infested by mistletoe in the Kozienice Forest District was $16 \%$, which should be taken into account when planning and managing forests.

2. Four main stand characteristics connected to mistletoe infection were found: Kraft class, crown density, site index, and age class. 
3. It was found that the most damaged trees were those that had the best sunlight conditions: tallest (Kraft class I), oldest, growing in a low density, and having the biggest crowns.

4. We are currently investigating mistletoe infection in the next 200 sample plots in the entire Kozienice Primeval Forest.

Author Contributions: All authors substantially contributed to all aspects of the article. Individual contributions: conceptualization, W.K. and R.W.; methodology, W.K. and R.W.; software, W.K.; investigation, W.K. and R.W.; data curation, W.K.; writing-original draft preparation, R.W.; writing-review and editing, W.K.; visualization, W.K.; and supervision, R.W. All authors have read and agreed to the published version of the manuscript.

Funding: This research was funded by the Warsaw University of Life Sciences (SGGW).

Conflicts of Interest: The authors declare no conflict of interest.

\section{References}

1. Kollas, C.; Gutsch, M.; Hommel, R.; Lasch-Born, P.; Suckow, F. Mistletoe-induced growth reductions at the forest stand scale. Tree Physiol. 2018, 38, 735-744.

2. Dobbertin, M.; Hilker, N.; Rebetez, M.; Zimmermann, N.E.; Wohlgemuth, T.; Rigling, A. The upward shift in altitude of pine mistletoe (Viscum album ssp. austriacum) in Switzerland-The result of climate warming? Int. J. Biometeorol. 2005, 50, 40-47.

3. Stypiński, P. Biologia i Ekologia Jemioty Pospolitej (Viscum album, Viscaceae) w Polsce; Instytut Botaniki im. W. Szafera, Polska Akademia Nauk.: Kraków, Poland, 1997; p. 117. ISBN: 83-85444-50-5.

4. Tsopelas, P.; Angelopoulos, A.; Economou, A.; Soulioti, N. Mistletoe (Viscum album) in the fir forest of Mount Parnis, Greece. Forest Ecol. Manag. 2004, 202, 59-65.

5. Iszkuło, G.; Armatys, L.; Ksepko, M.; Tomaszewski, D.; Giertych, M.J. Jemioła-Coraz poważniejsze zagrożenie dla polskich lasów. Las Polski 2019, 13-14, 13-15.

6. Pilichowski, S.; Filip, R.; Kościelska, A.; Żaroffe, G.; Żyźniewska, A.; Iszkuło, G. Wpływ Viscum album ssp. austriacum (Wiesb.) Vollm. na przyrost radialny Pinus sylvestris L. Sylwan 2018, 162, 452-459.

7. Borecki, T.; Keczyński, A. Atlas Ubytku Aparatu Asymilacyjnego Drzew Leśnych; Agencja Atut: Warszawa, Poland, $1992 ;$ p. 48. 